\title{
Kemungkinan Money Laundering Dalam Pemilihan Kepala Daerah
}

\author{
M. Arief Amrullah
}

\begin{abstract}
Abstak
One of the prominent activities of organized crime is to obtain profit that is obtained from illicit trafficking in drugs, comption (forinstance), or other proceds that derived or obtained, directly or inderectly, through the commission of an offence are entered into global financial system, so as if they become the proceed of the crime obtained from legal bussiness. Therefore, the effort to fight against money laundering is a dynamic process, and the organized criminals always seek the new method to embody their illegal aim. One of them hands over their financial contribution to local government head election (Pilkada). The practice of money laundering in the Pilkada election very possibly occurs, because of the conditions which gives opportunity to organized crimes group to laundry their money in Pilkada.
\end{abstract}

\section{Pendahuluan}

Kendati instrumen hukum yang mensaranai pelaksanaan Pilkada secara langsung' telah dikeluarkan, yaitu Pasal 56 ayat (1), yang menyatakan bahwa "Kepala daerah dan wakil hépala d'ái ah dipilih dalam satu pasangan calon yang dilaksanakan secara demokratis berdasarkan asas langsung...," bukan berarti masalah seputar itu sudah selesai, karena adanya ketentuan Pasal 59 ayat (1) Undang-undang
No. 32 Tahun 2004 yang menyatakan "Peserta pemilihan kepala daerah dan wakil kepala daerah adalah pasangan calon yang diusulkan secara berpasangan oleh partai politik atau gabungan partai politik". Hal ini berarti, yang mengusung pasangan calon tersebut (gubernur, wali kota, dan bupati) adalah partai politik atau gabungan partai politik. Jadi, kendaraannya adalah partai politik.

Dengan adanya Pasal 59 ayat (1) tersebut, maka masalah baru pun muncul, yaitu adanya

'Pilkada secara langsung sebagaimana yang diamanatkan dalam Undang-undang No. 32 Tahun 2004 tentang Pemerintahan Daerah (Lembaran Negara Tahun 2004 Nomor 125), tanggal 15 Oktober 2004 telah menunjukkan adanya perkembangan dalam teoridemokrasi. Dalam berbagai literatur tentang demokrasi dikatakan bahwa demokrasi terbagi dalam dua kategori dasar, yaitu langsung dan perwakilan. Dalam demokrasi langsung, semua warga, tanpa melalui pejabat yang dipilih atau diangkat dapat ikut dalam pembuatan keputusan politik. Akan tetapi, sistem ini hanya cocok untuk sejumlah kecil penduduk. Seringkali dicontohkan untuk demokrasi seperti ini adalah pada zaman Yunani kuno, karena jumlah penduduk relatif masih sedikit dibandingkan dengan sekarang, sehingga untuk melaksanakan demokrasi secara langsung tidak mungkin dilaksanakan. Akibatnya, yang paling mungkin dan umum adalah demokrasi perwakilan. 
kecenderungan partai politik tertentu untuk menyalahgunakan ketentuan Pasal 59 ayat (1), seperti minta sejumlah uang kepada pasangan calon, tentunya disertai dengain sejumlah alasan yang terkadang sulit untuk ditolak oleh pasangan calon. Ini sangat mungkin terjadi, karena satusatunya "kendaraan" adalah partai politik dan tidak ada kendaraan alternatif lainnya, sehingga ada ketergantungan kepada partai politik, dan apabila itu yang terjadi, berarti pasangan calon harus mengeluarkan dana ekstra yang tidak sedikit jumlahnya. Jika tidak berkenan mengikuti irama yang demikian itu, tentu tidak akan dapat "kendaraan", akibatnya akan kalah secara prematur. Sedangkan bagi yang berdana besar (entah dari mana sumbernya), tentu tidak banyak bermasalah, semuanya dapat diatur dengan uang. Padahal filosofi yang mendasari adanya pemilihan secara langsung tersebut adalah bahwa masyarakat hendak memilih sendiri calonnya yang berkualitas (tidak hanya pintar secara akademik, tapi juga berdedikasi tinggi), sehingga betul-betul sesuai dengan pilihan hati nuraninya. ${ }^{2}$

Mengingat dana yang dibutuhkan untuk menuju kepada kemenangan cukup besar, maka akan sangat memberi peluang bagi mereka yang punya dana besar yang diperoleh dari sumber yang tidak benar (illegal) untuk mencucikan uangnya melalui Pilkada. Terjadinya praktik pencucian uang (money laundering) dalam konteks pelaksanaan Pilkada ini tidak dapat dipisahkan dari peran kedua belah pihak yang saling membutuhkan. Di satu sisi, calon kepala daerah dan wakil kepala daerah membutuhkan dana yang besar, dan di sisi lain mereka yang mempunyai uang banyak yang diperoleh dari sumber yang tidak bersih (misalnya hasil korupsi, judi, dan lain sebagainya) berupaya mencucikan uangnya itu di antaranya melalui Pilkada. Karena itu, dalam konteks pelaksanan Pilkada, terjadinya kolusi (permupakatan) atau persekongkolan (konspirasi) sulit untuk dihindari, dan itu dilakukan secara rahasia, tentunya pula disertai dengan kesepakatan-kesepakatan secara rahasia lainnya antara penyandang dana dan calon penerima dana manakala sang calon terpilih.

\section{Money Laundering di Seputar Pilkada}

Perubahan terbaru dalam bidang ekonomi global telah memberikan keuntungan bagi penjahat tingkat dunia, yaitu dengan memanfaatkan peningkatan arus barang, uang, dan orang secara lintas batas, maka organisasi kejahatan internasional telah memperluas jangkauan wilayah mereka dan hubungan mereka dengan kekuasaan pemerintahan setempat. Perkembangan itu menimbulkan berbagai ancaman, baik langsung maupun tidak langsung terhadap kepentingan nasional.

Money Laundering yang merupakan bagian dari kejahatan terorganisasi, pada dasarnya, termasuk salah satu kejahatan

${ }^{2}$ Dengan sistem yang dibangun oleh Undang-undang No. 32 Tahun 2004 , tidak perlu berbicara pemimpin yang berdedikasi tinggi, jujur dan mengabdikan dirinya bagi pembangunan dan pengembangan daerah, tetapi seorang preman pun, misalnya, dapat menjadi kepala daerah dan wakil kepala daerah asalkan mempunyai banyakuang. Uang yang digunakan tidak perlu uang sendiri, yang penting dapat mencari seponsor (penyandang dana) dengan konsekuensi akan mengembalikannya dalam bentuk proyek-proyek atau kemudahan-kemudahan lainnya yang disepakati dengan penyandang dana. 
terhadap pembangunan dan kesejahteraan sosial yang menjadi pusat perhatian dan keprihatinan internal nasional dan eksternal internasional. Perhatian dan keprihatinan dunia internasional terhadap kejahatan pencucian uang itu sangat beralasan karena ruang lingkup dan dimensinya begitu luas sehingga kegiatannya mengandung ciri-ciri sebagai organized crime, white-collar crime, corporate crime, dan transnational crime. Bahkan, dengan kemajuan teknologi informasi, money laundering dapat menjadi salah bentuk dari cyber crime.

Berdasarkan uraian di atas, timbu! pertanyaan: "apakah yang dimaksud dengan money laundering tersebut?" Terdapat bermacam-macam pengertian tentang money loundering. Money laundering merupakan sebuah istilah yang kali pertama digunakan di Amerika Serikat. Istilah tersebut menunjuk kepada pencucian hak milik mafia, yaitu hasil usaha yang diperoleh secara gelap yang dicampurkan dengan maksud menjadikan seluruh hasil tersebut seolah-olah diperoleh dari sumber yang sah. Singkatnya, istilah money laundering kali pertama digunakan dalam konteks hukum dalam sebuah kasus di Amerika Serikat pada tahun 1982. Kasus tersebut menyangkut denda terhadap pencucian uang hasil penjualan kokain Colombia. Dalam perkembangannya, proses yang dilakukan lebih kompleks lagi dan sering menggunakan cara mutakhir sedemikian rupa sehingga seolah-olah uang yang diperoleh benar-benar alami. $^{3}$

Dalam Section 81 (3) dari Proceeds of Crime Act 1987 (Cth) Australia, merumuskan money laundering sebagai berikut, yaitu seseorang dapat dikatakan melakukan pencucian uang jika. ${ }^{4}$

a) seseorang yang melakukan baik langsung maupun tidak langsung, dalam suatu transaksi yang menggunakan uang, atau kekayaan lainnya, yang diperoleh dari hasil kejahatan; atau

b) seseorang menerima, memiliki, menyembunyikan, memberikan atau memasukan uang ke Australia, atau kekayaan lainnya, yang diperoleh dari hasil kejahatan; dan seseorang yang mengetahui, atau seharusnya menduga bahwa uang atau kekakayaan lainnya itu diperoleh atau diketahui, baik langsung maupun tidak langsung dari sejumlah bentuk kegiatan yang melawan hukum."

Selanjutnya, menurut ketentuan Article 38 (3) Finance Act 1993 Luxembourg (Criminal definition of money laundering), ${ }^{5}$ pencucian uang dapat didefinisikan sebagai suatu perbuatan yang terdiri atas penipuan, menyembunyikan, pembelian, pemilikan, menggunakan, menanamkan, penempatan, pengiriman, yang dalam undang-undang yang mengatur menganai

${ }^{3}$ United Nations Economic and Social Council, "Strengthening Existing International Cooperation in Crime Prevention and Criminal Justice, Including Technical Cooperation in Developing Countries, with Special Emphasis on Combating Organized Crime," Commission on Crime Prevention and Criminal Justice, First session, Vienna, 21-30 April 1992.

${ }^{4}$ Gabriel A. Moens, "Bank Confidentiality and Govemmental Control of Exchange Operations and of Their Unlawful Effects - Australia," dalam Paolo Bernasconi (ED), "Money Laundering and Banking Secrecy," General Report of XIVth International Congress of Comparative Law, Athens, 1994, hlm. 36.

5 "Prevention of Money Laundering in Luxembourg," dalam Paolo Bernasconi (ED), "Money Launderingand Banking Secrecy," General Report of XIVth Intemational Congress of Comparative Law, Athens, 1994, hlm. 170. 
kejahatan atau pelanggaran secara tegas menetapkan status perbuatan tersebut sebagai tindak pidana khusus, yaitu suatu keuntungan ekonomi yang diperoleh dari tindak pidana lainnya.

Tidak jauh berbeda dengan pengertian di atas, Undang-undang No. 25 Tahun 2003 tentang Perubahan atas Undang-undang. No. 15 Tahun 2002 (Lembaran Negara Tahun 2003 Nomor 108), tanggal 13 Oktober 2003 dalam Pasal 1 angka 1 merumuskan:

"Pencucian uang adalah perbuatan menempatkan, mentransfer, membayarkan, membelanjakan, menghibahkan, menitipkan, membawa ke luar negeri, menukarkan, atau perbuatan lainnya atas harta kekayaan yang diketahuinya atau patut diduga merupakan hasil tindak pidana dengan maksud untuk menyembunyikan, atau menyamarkan asal usul harta kekayaan sehingga seolah-olah menjadi harta kekayaan yang sah".

Financial Action Task Force on Money Laundering (FATF) merumuskan "money laundering adalah proses menyembunyikan atau menyamarkan asal-asul hasil kejahatan." Proses tersebut untuk kepentingan penghilangan jejak sehingga memungkinkan pelakunya menikmati keuntungan-keuntungan itu dengan tanpa mengungkap sumber perolehan. Penjualan senjata secara ilegal, penyelundupan, dan kegiatan kejahatan terorganisasi, contohnya perdagangan obat dan prostitusi, dapat menghasilkan jumlah uang yang banyak. Penggelapan, perdagangan orang dalam (insider trading); penyuapan, dan bentuk penyalahgunaan komputer dapat juga menghasilkan keuntungan yang besar dan menimbulkan dorongan untuk menghalalkan (legitimise) hasil yang diperoleh melalui money laundering.

Pencucian keuntungan yang diperoleh dari hasil kejahatan tersebut, tujuannya adalah untuk mengaburkan atau menghilangkan jejak sumber atau asal perolehannya, sehingga (harapan) sulit dilacak oleh aparat penegak hukum. Adapun metode dalam proses pencucian uang meliputi tiga tahap. Pertama, adalah placement harta kekayaan ke dalam sistem keuangan melalui bank atau lembaga keuangan lainnya. Negara-negara harus ada persyaratan pelaporan terhadap transaksi tunai yang besar, di mana transaksi-transaksi tersebut dilakukan melalui jumtah yang lebih besar dengan memecahnya ke dalam transaksi-transaksi kecil, yaitu yang disebut dengan smurfing. Di samping itu, pendekatan alternatif lainnya adalah secara pisik melakukan penyelundupan dalam jumlah besar uang tunai ke luar negeri dan menyimpannya di negara di mana persyaratan pelaporannya kurang ketat. Kedua, adalah layering, yaitu memisahkan dana (kekayaan) dari asalnya dan dilakukan untuk menyamarkan apa yang sebenarnya dan membuat tidak jelas dalam melakukan penelusurannya. Tahap ketiga adalah integration, yang membutuhkan penempatan kekayaan yang diperoleh dari hasil kejahatan ke dalam ekonomi yang sah tanpa menimbulkan kecurigaan asal perolehannya. Contoh untuk tahap ketiga ini adalah pembelian real estate atau dapat melibatkan bank di negara-negara yang tidak mempunyai peraturan mengenai money laundering. ${ }^{6}$

${ }^{6} \mathrm{M}$. Arief Amrullah, Money Laundering, Tindak Pidana Pencucian Uang, Bayumedia Publishing, Malang, 2003, hlm. 11. 
Di Australia, umumnya metode yang digunakan untuk melakukan pencucian uang terdiri atas :?

a) real estate, kekayaan atau aset lainnya dibeli dengan menggunakan nama samaran, seperti perusahaan, keluarga atau teman.

b) concealed identity, dana didepositokan, atau dipindahkan melalui rekening dengan nama samaran (tidak sebenarnya) seperti halnya perusahaan, keluarga atau teman.

c) funds sent overseas, hasil kejahatan dikirim ke luar negeri dengan menggunanakn beberapa sarana termasuk telegraphictransfer, travelers' cheques, atau bahkan uang tersebut dibawa secara fisik ke luar negeri.

d) false income, hutang palsu dibuat dengan jalan si pelaku seolah telah berutang dengan orang lain dan pembayaran itu dilakukan dari hasil kejahatan yang disediakan untuk orang tersebut. Cara ini meliputi deposito palsu atas kekayaan yang dimiliki oleh pelaku, pinjaman keluarga, atau pinjaman kepada perusahaan yang dimiliki oleh pelaku. Kemungkinan lain pinjaman palsu tersebut dibuat dengan jalan si pelaku seolah berutang kepada orang lain dan utang tersebut akan dibayar kembali dengan hasil kejahatan.

e) mingling, dana dijalankan melalui struktur bisnis agar dana tersebut seolah menjadi bagian dari kegiatan bisnis yang sah.

Sehubungan dengan pelaksanaan Pilkada yang dilaksanakan pada bulan Juni 2005, kemungkinan besar praktik pencucian uang dapat pula dilakukan dengan cara mendukung salah satu pasangan calon kepala daerah melalui kucuran dana miliaran rupiah. Jika yang didukung terpilih, maka sesuai dengan kesepakatan akan ada kemudahan-kemudahan dalam berinvestasi, baik dalam bidang real estate, perkebunan, pertambangan, industri, pariwisata, dan lain sebagainya, sehingga hasil yang diperoleh dari usaha-usaha itu seolah benar-benar diperoleh dari usaha yang sah dan benar, sehingga tidak tampak telah terjadi pencucian uang. Praktik seperti itu sangat mungkin terjadi, mengingat upayaupaya untuk membersihkan uang hasil kejahatan dapat dilakukan dengan berbagai cara, termasuk dalam pelaksanaan Pilkada.

Mengingat pencucian uang merupakan bagian dari kejahatan terorganisasi (organized crime), dalam oprasionalnya mengenal jaringan, ${ }^{8}$ yang pada intinya sebagai berikut:

1. lapisan bawah terdapat para pelaksana penyediajasa yang tidak sahyangdinamakan racketeers, lapisan ini kemungkinan besar direkrut dari para preman yang biasanya bergabung pula dalam organisasiorganisasi preman;

2. lapisan tengah terdapat para pengelola yang disebut organizer, yang terdiri dari dari orang-orang profesional yang bergerak di bidang bisnis, politik (koneksi) dan penegak hukum;

3. lapisan atas terdapat para penyandang dana, yang dinamakan financiers, yaitu para pengusaha kelas kakap dalam bidang real estate, kontraktor, industri, dan lain-lain.

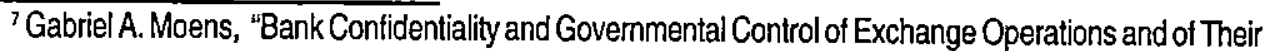
Unlawful Effects - Australia," dalam Paolo Bernasconi (ED), "Money Laundering and Banking Secrecy," General Report of XIVth International Congress of Comparative Law, Athens, 1994, hlm. 35.

${ }^{8}$ Mardjono Reksodiputro, "Kejahatan Terorganisasi dan Kejahatan oleh Organisasi (Suatu Tinjauan dari segi Kriminologi)," Jurnal Polisi Indonesia, Tahun 2, April 2000-September 2000, Jakarta, hlm. 41. 
Ancaman atau akibat yang ditimbulkannya pun sangat dahsyat (insidious) dalam berbagai bidang dan manifestasinya, yang antara lain meliputi: ${ }^{9}$

"the threat to sovereignty; the threat to societies; the threat to individuals; the threat to national stability and state control; the threat to democratic values and public institutions; the threat to national economies; the threat to financial institutions; the threat to democratization and privatization; the threat to development."

Di samping itu, kejahatan tersebut juga mengganggu dan mengacaukan lembagalembaga sosial dan ekonomi, menyebabkan longgarnya pelaksanaan proses demokrasi, merusak pembangunan dan menyelewengkan hasil-hasil yang sudah dicapai, mengorbankan penduduk, memperangkap dan bahkan memperbudak golongan-golongan masyarakat.

Oleh karena itu, sebagaimana yang ditulis oleh Hans G. Nilsson, ${ }^{10}$ money laundering telah menjadi permasalahan yang menarik bagi masyarakat dunia pada hampir dua dekade dan khususnya Dewan Eropah (Council of Europe) yang merupakan organisasi internasional pertama, Dalam Rekomendasi Komite para menteri dari tahun 1980 telah mengingatkan masyarakat internasional akan bahayabahayanya terhadap demokrasi dan Rule of Law. Dalam rekomendasi tersebut juga dinyatakan, bahwa transfer dana hasil kejahatan dari negara satu ke negara lainnya dan proses pencucian uang kotor melalui penempatan dalam sistem ekonomi telah meningkatkan permasalahan serius, baik dalam skala nasional maupun internasional. Namun demikian, hampir satu dekade rekomendasi tersebut tidak berhasil menarik perhatian masyarakat internasional terhadap masalah tersebut. Baru kemudian setelah meledaknya perdagangan gelap narkotika pada tahun 1980-an, telah menyadarkan masyarakat internasional bahwa money laundering telah menjadi sebuah ancaman terhadap seluruh keutuhan sistem keuangan dan pada akhirnya dapat menimbulkan permasalahen serius terhadap stabilitas demokrasi dan rule of Law.

Sebagaimana telah disinggung sebelumnya, - bahwa tujuan utama dilakukannya jenis kejahatan itu adalah untuk menghasilkan keuntungan, baik bagi individu maupun kelompok yang melakukan kejahatan tersebut. Menurut suatu perkiraan baru-baru ini, hasil dari kegiatan money laundering di seluruh dunia, dalam perhitungan secara kasar, berjumlah satu triliun dolar setiap tahun. Danadana gelap tersebut akan digunakan oleh pelaku untuk membiayai kegiatan kejahatan selanjutnya. Selain itu, Dana Moneter Internasional (IMF) menyatakan bahwa jumlah keseluruhan money laundering di dunia diperkirakan antara dua sampai dengan lima persen produk domestik bruto dunia. Apabila menggunakan statistik tahun 1996, persentase tersebut menunjukkan bahwa money laundering berkisar antara 590 milyar US Dolar sampai

${ }^{9}$ Dokumen PBB No. E/CONF.88/2 tanggal 18 Agustus 1994 dan telah dibicarakan dalam World Ministerial Conference on Organizied Transnational Crime di Naples, 21 - 23 November 1994, "Problem and Dangers Posed by Organized Transnational Crime in the Various Regions of the World," disampaikan dalam Kongres PBB ke-9, the Prevention of Crime and the Treatment of Offenders, Kairo, 29 April-8 Mei 1995, him. 24-28.

${ }^{10}$ Hans G. Nilsson, "Preface," dalam Paolo Bernasconi (ED), "Money Laundering and Banking Secrecy," General Report of XIVth International Congress of Comparative Law, Athens, 1994, hlm. ix. 
dengan 1,5 triliun US dolar. Angka terendah, kirakira setara dengan nilai keseluruhan produk ekonomi Spanyol. Selain itu, berdasarkan perkiraan Financial Action Task Force on Money Laundering (FATF) bahwa setiap tahun di Eropah dan Amerika Utara berkisar antara 60 hingga 80 milyar dollar AS telah terjadi pencucian dalam sistem keuangan.

Belum termasuk negara-negara di Asia, sudah berapa banyak dana yang dicuci dari hasil kejahatan. Demikian juga halnya dengan Indonesia, yang tengah mencoba melaksanaan demokrasi langsung sebagaimana yang antara lain terimplementasi dalam Pilkada tahun 2005. Di arena ini, ada kecenderungan bahwa pencucian uang telah terjadi, meskipun belum ada bukti yang menunjukkan demikian. Karena memang, proses yang demikian itu dilakukan dengan halus dan licin.

\section{Penanggulangan dengan Hukum Pidana}

Menanggulangi (kejahatan), berarti usaha untuk mengendalikan kejahatan agar berada dalam batas-batas toleransi masyarakat." Ini berarti, bahwa kejahatan (apa pun jenisnya) tiúák muırkin dienyahkan secara total dari muka bumi, karena ada wilayah-wilayah tertentu yang di luar jangkauan hukum (the area of no enforcement), sehingga yang mungkin untuk dilakukan adalah meminimalkan, bukan menghapuskan. Dalam politik kriminal (criminal policy), upaya menanggulangi kejahatan meliputi dua pendekatan, yaitu melalui jalur penal (hukum pidana) dan non-penar (tidak menggunakan hukum pidana).

Dalam bagian ini, penulis lebih menekankan pada pendekatan penal sebagaimana yang terimplementasi dalam Undang-undang No. 32 Tahun 2004, dan mencoba menelaah apakah ketentuan pidana yang tercantum dalam Pasal 116 ayat (6) dan ayat (7) jo. Pasal 83 ayat (3) dan Pasal 85 ayat (1) dan ayat (2) akan mampu mencegah kemungkinan terjadinya praktik pencucian uang dalam Pilkada. Demikian juga dengan ketentuan Pasal 3 ayat (1) huruf $d$, dan Pasal 6 ayat (1) huruf d dan e Undangundang No. 25 Tahun 2003 tentang Perubahan atas Undang-undang No. 15 Tahun 2002 tentang Tindak Pidana Pencucian uang.

Untuk menjawab pertanyaan itu, perlu ditelusuri terlebih dahulu apakah ada hubungan antara kemungkinan pratik pencucian uang dengan pelaksanaan Pilkada. Untuk mencari hubungan tersebut, maka dapat dikaitkan dengan ketentuan Pasal 83 Undang-undang No. 32 Tahun 2004 yang mengatur mengenai sumbangan dana kampanye kepada pasangan calon kepala daerah dan batas-batas yang diperkenan. Dalam Pasal 83 ayat (1) ditentukan bahwa dana kampanye dapat diperoleh dari "pasangan calon; partai politik dan/atau gabungan partai politik yang mengusulkan; sumbangan pihak-pihak lain yang tidak mengikat yang meliputi sumbangan perseorangan dan/ atau badan hukum swasta." Namun, dari ketiga sumber pendanaan itu, undang-undang hanya membatasi kepada penyumbang perseorangan dan/atau badan hukum swasta, yaitu sebagaimana diatur dalam Pasal 83 ayat (3) bahwa sumbangan dana kampanye dari perseorangan dilarang melebihi $R p 50.000 .000,00$, dan dari badan hukum swasta dilarang melebihi Rp. $350.000 .000,00$. Pelanggaran terhadap

"Mardjono Reksodiputro, "Sistem Peradilan Pidana Indonesia (Peran Penegak Hukum Melawan Kejahatan)," dalam Mardjono Reksodiputro, Hak Asasi Manusia dalam Sistem Peradilan Pidana, Jakarta, 1994, him. 84. 
batas yang diperkenankan itu, diancam berdasarkan ketentuan Pasal 116 ayat (6) dengan pidana penjara paling singkat empat bulan atau paling lama dua puluh empat bulan dan/atau denda paling sedikit $\mathrm{Rp} 200.000 .000,00$ atau paling banyak satu miliar rupiah. Pidana yang dijatuhkan itu, baik kepada penerima maupun pemberi (penyumbang) dana kampanye, walaupun dalam ketentuan Pasal 83 ayat (3) batasan jumlah dana itu ditujukan kepada penyumbang.

Demikian juga sebaliknya dengan ketentuan Pasal 85 ayat (1)-nya, melarang kepada pasangan calon kepala daerah untuk menerima sumbangan atau bantuan lain untuk kampanye yang berasal dari: negara asing, lembaga swasta asing, lembaga swadaya masyarakat asing dan warga negara asing; penyumbang atau pemberi bantuan yang tidak jelas identitasnya; pemerintah, BUMN dan BUMD. Untuk itu, kepada pasangan calon yang menerima sumbangan itu tidak dibenarkan menggunakannya, karenanya wajib melaporkannya kepada KPUD (Pasal ' 85 ayat (2). Pelanggaran atas ketentuan ini, maka baik yang menerima maupun yang memberi dana kampanye sebagaimana diatur dalam Pasal 116 ayat (7) diancam dengan pidana penjara paling singkat empat bulan atau paling lama dua puluh empat bulan dan/atau denda paling sedikit $\mathrm{Rp} 200.000 .000,00$ atau paling banyak satu miliar rupiah.

Berdasarkan ketentuan tersebut, maka yang menjadi pertanyaan apakah ketentuan itu akan efektif dalam menaggulangi praktik pencucian uang seputar pelaksanan Pilkada, mengingat metode yang digunakan untuk melakukan pencucian uang sebagaimana telah dikemukakan' di atas dapat dengan berbagai cara. Pengucuran dana kepada pasangan calon peserta Pilkada dapat saja dilakukan dengan melalui beberapa orang atau badan. hukum swasta dan memecahnya sesuai dengan jumlah yang diperkenankan oleh Pasal 83 ayat (3) atau pun larangan yang diatur dalam Pasal 85 ayat (1) dan ayat (2) Undang-undang No. 32 Tahun 2004, sehingga lepas dari jaringan Pasal 116 ayat (6) dan ayat (7) Undang-undang No. 32 Tahun 2004.

Selanjutnya, apabila memperhatikan batasan yang disebutkan dalam Pasal 83 ayat (3) tersebut, dan dikaitkan dengan kebutuhan dana puluhan miliar rupiah (mungkin pula mencapai ratusan miliar rupiah), pertanyaannya apakah bagi pasangan calon pemula (bukan kepala daerah yang akan mencalonkan diri untuk kedua kalinya) dan bukan sebagai pengusaha besar mampu menyediakan dana sebesar itu untuk membiayai kegiatannya dalam Pilkada, demikan juga jika kepala daerah yang ada hendak lagi mencalonkan diri untuk kedua kalinya. Jika jawabannya "ya" (mampu), maka pertanyaan selanjutnya: dari mana dana itu asalnya, apakah bukan dari hasil kejahatan, korupsi misalnya, atau hasil dari kejahatan lainnya. Ini jika diasumsikan bahwa batasan jumlah dana yang disebutkan dalam Pasal 83 ayat (3) adalah hanya "sumbangan", yang berarti hanya sekedar membantu untuk kegiatan kampanye.Padahal dana untuk kegiatan kampanye pun pada dasarnya membutuhkan dana besar, karena itu mengakali ketentuan Pasal 83 ayat (3) guna menghindari jeratan ketentuan Pasal 116 ayat (6), demikian juga halnya dengan upaya menghindari jeratan Pasal 116 ayat (7) atas pelanggaran ketentuan Pasal 85 ayat (1) dan ayat (2) sangat mungkin dilakukan. Karena itu, penelusuran adanya praktik pencucian uang dalam kegiatan ini, sebenarnya sudah dapat dilakukan. 
Selain itu, terhadap ketentuan Pasal 85 ayat (1) kemungkinan besar dapat pula diakali dengan mengggunakan metode sebagaimana yang dikemukakan oleh Gabriel A. Moens di atas, yaitu melalui concealed identity, dana didepositokan, atau dipindahkan melalui rekening dengan nama samaran (tidak sebenarnya) seperti halnya perusahaan, keluarga atau teman; dan funds sent overseas, hasil kejahatan dikirim ke luar negeri dengan menggunanakan beberapa sarana termasuk telegraphic transfer, travelers' cheques, atau bahkan uang tersebut dibawa secara fisik ke luar negeri. Karena itu, bagi negara asing, lembaga swasta asing, lembaga swadaya masyarakat asing dan warga negara asing, sangat mungkin mengirimkan uangnya ke Indonesia melalui suatu jaringan dan dikelola dengan baik yang selanjutnya disalurkan kepada pasangan calon kepala daerah yang membutuhkan dana besar melalui semacam agen atau tangan kanan pengelola dana (perorangan atau kelompok) yang ditempatkan di daerah-daerah baik di kabupaten maupun di propinsi. Hubungan intensip, awalnya dibangun antara agen dengan calon kepala daerah atau melalui tim sukses. Eerbagai negosiasi dibicarakan di level ini, sebelum diteruskan ke level atas untuk pencairan dana.

Adanya kemungkinan terjadinya money laundering dalam Pilkada, apakah ketentuan pidana dalam Undang-undang No. 25 Tahun 2003 tentang Perubahan atas Undang-undang No. 15 Tahun 2002 tentang Tindak Pidana Pencucian Uang sudah dapat mengantisipasi terjadinya money laundering di arena baru tersebut (Pilkada). Pasal 3 ayat (1) huruf $d$
Undang-undang ini menentukan bahwa setiap orang yang dengan sengaja menghibahkan atau menyumbangkan harta kekayaan yang diketahuinya atau patut diduganya merupakan hasil tindak pidana, baik atas namanya sendiri maupun atas nama pihak lain, diancam dengan pidana penjara paling singkat lima tahun dan paling lama lima belas tahun dan denda paling sedikit seratus juta rupiah dan paling banyak lima belas miliar rupiah. Demikian juga dengan setiap orang yang menerima atau menguasai hibah atau sumbangan sebagaimana diatur dalam Pasal 6 ayat (1) huruf $d$ dan $e$ diancam dengan pidana yang sama sebagaimana diatur dalam Pasal 3 ayat (1) huruf $d$ di atas.

Dilihat dari sanksi pidana yang diancamkan, ketentuan yang diatur dalam Undang-undang No. 25 Tahun 2003 tentang Perubahan atas Undang-undang No. 15 Tahun 2002 tentang Tindak Pidana Pencucian Uang lebih tinggi daripada yang diatur dalam Undang-undang No. 32 Tahun 2004. Hal itu wajar, karena Undangundang No. 32 Tahun 2004 pada dasarnya merupakan undang-undang administrasi yang bersanksi pidana, dan menurut Andi Hamzah ${ }^{12}$ perundang-undangan administrasi yang bersanksi pidana itu, biasanya berupa delik pelanggaran saja. Akan tetapi di Indonesia menjadi lain, karena ada perundang-undangan administrasi yang sanksinya sampai pidana mati. Ini berbeda dengan Belanda.

Di Indonesia, kebjjakan yang mencantumkan ketentuan pidana dalam Undang-undang No. 32 Tahun 2004, pada hakikatnya tidak dapat dilepaskan dari kecenderungan kebijakan legislatif yang selalu mencantukan ketentuan pidana dalam hukum administrasi. Hukum

${ }^{12}$ Andi Hamzah, "Hukum Pidana Khusus (Economic Crime)," Bahan Penataran Nasional: Hukum Pidana dan Kriminologi, Hotel Gracia, Semarang, 23-30 Nopember 1998, hlm. 1 
administrasi pada dasamya merupakan hukum mengatur atau hukum pengaturan, yaitu hukum yang dibuat dalam melaksanakan kekuasaan mengatur atau kekuasaan pengaturan, sehingga penggunaan istilah hukum pidana administrasi sering pula disebut dengan hukum pidana mengenai pengaturan atau hukum pidana dari aturan-aturan. Dengan demikian, hukum pidana administrasi itu merupakan perwujudan dari kebijakan menggunakan hukum pidana sebagai sarana untuk menegakkan atau melaksanakan norma yang ada dalam hukum administrasi tersebut. ${ }^{13}$

Selanjutnya, dilihat dari segi kebijakan pencantuman ketentuan pidana, khususnya pidana denda, baik yang diatur dalam Undangundang No. 32 Tahun 2004 maupun Undangundang No. 25 Tahun 2003 tentang Perubahan atas Undang-undang No. 15 Tahun 2002 tentang Tindak Pidana Pencucian Uang, apakah akan benar-benar dirasakan sebagai sanksi oleh pelaku tindak pidana pencucian uang, terutama jika pelakunya adalah suatu badan hukum atau korporasi. Memang, para ahli kriminologi sebagaimana ditulis oleh Harry V. Ball dan Lawrence M. Friedman ${ }^{14}$ bahwa pada umumnya menyetujui menggunakan denda sebagai sanksi atas pelanggaran hukum pidana, sebab dengan denda, berarti keuntungan yang telah diperoleh oleh si pelaku (business organization) akan menjadi hilang (karena didenda). Pidana yang demikian ini (denda) akan dapat mencegah perolehan keuntungan melalui kejahatan.

Mengkritisi kebijakan penal yang berupa pidana denda tersebut, Mardjono Reksodiputro ${ }^{15}$ menulis bahwa ancaman pidana yang tinggi dengan tujuan agar perusahaan atau organisasi (kejahatan, pen.) merasakan kerugian atas perbuatannyaitu, karena keuntungan perusahaan akan berkurang. Meskipun begitu, apabila pencantuman ancaman pidana yang tinggi didasarkan atas asumsi bahwa perusahaan memang sangat berorientasi pada keuntungan berupa uang dan para pemegang saham merasakan kerugian akan mempengaruhi perusahaan untuk tidak lagi melakukan pelanggaran hukum pidana, maka asumsi yang demikian itu tidak akan banyak artinya bagi perusahaan besar atau yang bersifat konglomerasi. Karena itu, Reksodiputro sampai pada kesimpulan bahwa denda yang tinggi belum tentu mampu menghalangi perusahaan melakukan kejahatan, karena para pemegang sahamnya menafsirkan hal itu sebagai risiko yang harus diambil untuk memperoleh keuntungan yang besar. Selain itu, dikaitkan dengan penggajian para manajer profesional perusahaan, denda

${ }^{13}$ Barda Nawawi Arief, "Penggunaan Sanksi Pidana dalam Hukum Administrasi," Makalah disampaikan pada Penataran Nasional Hukum Pidana dan Kriminologi, Diselenggarakan oleh ASPEHUPIKI bekerjasama dengan Fakultas Hukum Universitas Surabaya, Hotel Surya Prigen - Pasuruan, 13-19 Januari 2002, hlm. 2-3.

${ }^{14}$ Harry V. Ball and Lawrence M. Friedman, "The Use of Criminal Sacntions in the Enforcement of Economic Legislation:ASociological View, dalam GilbertGeis and RobertF. Meier, (ED), White-collar Crime:Offenses in Business, Politics, and the Professions, The Free Press, A Division of Macmillan Publishing Co., Inc., New York, 1977, hlm. 320.

${ }^{15}$ Mardjono Reksodiputro, Kemajuan Pembangunan Ekonomi dan Kejahatan, Buku Kesatu, Pusat Pelayanan Keadilan dan Pengabdian Hukum, Lembaga Kriminologi, Universitas Indonesia, Jakarta, 1997, hlm. 119-123. Lihat pula Mardjono Reksodiputro, Bunga Rampai Permasalahan dalam Sistem Peradillan Pidana, Buku Kelima, Pusat Pelayanan Keadilan dan Pengabdian Hukum, Lembaga Kriminologi, Universitas Indonesia, Jakarta, 1997, hlm. 143. 
yang tinggi itu pun tidak ada pengaruhnya karena semuanya telah diatur dalam kontrak.

Sejalan dengan pandangan itu, Balakrishnan menulis ${ }^{16}$ bahwa memang pidana denda itu sesuai diterapkan terhadap penusahaan atau korporasi, ${ }^{17}$ karena korporasi tidak dapat dijatuhi pidana penjara, akan tetapi hal itu saja (denda) masih belum cukup. Karena, sanksi yang berupa pidana denda tidak akan pernah dirasakan sebagai hukuman. Anggapan bahwa denda sebagai hukuman hanyalah di atas kertas. Untuk itu, perlu ada ketentuan khusus, seperti menghentikan kegiatan korporasi untuk sementara waktu dan untuk mengelola korparasi itu dilakukan oleh negara.

Dengan demikian, alternatif sanksi selain pidana denda, baik yang dikemukakan oleh Reksodiputro maupun Balakrishnan di atas, sebenarnya didasarkan atas keraguan akan kemampuan sanksi berupa pidana denda itu apabila dikenakan kepada perusahaan atau korporasi, terlebih jika korporasi itu sifatnya giant corporation. Mencari alternatif sanksi yang tepat untuk dikenakan terhadap korporasi, Kadish $^{18}$ mengajukan alternatif berupa memberikan "cap" jahat kepada korporasi. Menurut Kadish, memberikan cap jahat itu dapat dilakukan seperti merusak nama baik korporasi dalam kegiatan bisnisnya, sehingga akan mempengaruhi keadaan ekonominya. Dengan sanksi yang berupa stigma atau cap itu, akan dapat mencegah korporasi melakukan

${ }^{16}$ Balakrishnan, "Reform of Criminal in India Some Aspects," dalam Resource Material Series No. 6, UNAFEl, Fuchu, Tokyo, Japan, Oktober 1973, hlm. 48.

${ }^{17}$ Steven Box, Power, Crime, and Mystification, Tavistock Publication, London \& New York, 1983, hlm. 22, membedakan kejahatan korporasi sebagai berikut: a) Crime for corporation (corporate crime), kejahatan yang dilakukan oleh korporasi untuk mencapai tujuan korporasi berupa perolehan keuntungan untuk kepentingan korporasi; b) Crime against corporation (employee crime), kejahatan terhadap korporasi, misalnya seorang bendahara yang mencuri uang korporasi, dalam hal ini yang menjadi sasaran kejahatan adalah korporasi, sehingga korporasi yang menjadi korban; c) Criminal corporations, korporasi digunakan sebagaj sarana untuk melakukan kejahatan. Selanjutnya, Sahetapy, Kejahatan Korporasi, Eresco, Bandung, 1994, hlm. 29, membedakan: a) ada korporasi yang didirikan secara legal dengan tujuan legal pula, namun dalam aktivitasnya mungkin atau terpaksa atau terdo-rong menjalankan suatu kegiatan yang kemudian dikualifikasikan sebagai kejahatan korporasi; b) ada pula korporasi yang tampak didirikan secara legal, padahal dinding luarnya saja yang legal, tujuannya adalah melakukan kejahatan, sehingga sejak semula muatan dan kegiatannya bersifat illegalyang ditutupi oleh dinding korporasi yang legal. Mardjono Reksodiputro, "Kejahatan Terorganisasi dan Kejahatan oleh Organisasi (Suatu Tinjauan dari segi Kriminologi)," Jumal Polisi Indonesia, Tahun 2, April 2000September 2000, Jakarta, hlm 39-40, kejahatan terorganisasi mengacu pada suatu organisasi rahasia. Kejahatan terorganisasi ini mempunyai jaringan yang luas hingga sampai pada organisasi bisnis yang sah. Organisasi bisnis yang mempunyai hubungan dengan kejahatan terorganisasi adalah a) perusahaan kedok, didirikan memang untuk menutupi kegiatan kejahatan, apabila terbongkar maka perusahaan ini segera bubar; c) perusahaan sah, melakukan kegiatan melanggar hukum sebagai bisnis sampingan, sebagian besar kegiatan bisnisnya sah, tetapi di samping itu secara teratur perusahaan ini juga digunakan untuk kegiatan kejahatan kejahatan; c) perusahaan dan pemilik serta pengurusnya selalu bergerak dalam bidang kegiatan bisnis yang sah, namun mereka membiarkan dan memanfaatkan adanya kegiatan kejahatan yang berada di sekitar mereka.

${ }^{18}$ Sanford H. Kadish, "Some Observations on the Use of Criminal Sacntions in Enforcing Economic Regulations," dalam Gilbert Geis and Robert F. Meier, (ED), White-Collar Crime: Offenses in Business, Politics, and the Professions, The Free Press, ADivision of Macmillan Publishing Co., Inc., New York, 1977, hlm. 304. 
kejahatan.

Sebagaimana telah dikemukakan sebelumnya bahwa pencucian uang sebagai bagian dari kejahatan terorganisasi dapat melakukan berbagai cara untuk mencapai tujuannya, karena itu dalam The Forty Recommendations yang dikeluarkan oleh FATF (Financial Action Task Force on Money Laundering) dan telah direvisi pada bulan Juni 2003 mengemukakan bahwa "lembaga keuangan harus memberi perhatian khusus terhadap hubungan usaha dan transaksi dengan orang, termasuk perusahaan..." Adanya peringatan tersebut, karena FATF khawatir apabila korporasi digunakan untuk mendukung pendanaan teroris.

Kekawatiran FATF itu, baru pada tataran pengembangan kemungkinan penguatan pendanaan untuk kegiatan teroris, padahal dalam perkembangannya praktik pencucian uang tidak menutup kemungkinan merambah ke wilayah pelaksanaan Pilkada di Indonesia. Untuk perkembangan selanjutnya, seyogyanya FATF juga mulai mengarahkan perhatiannya kepada pengaruh negatif dari pelaksanaan demokrasi, yaitu seperti sumbangan dana kampanye pemilihan umum, baik yang terjadi di negara maju maupun negara berkembang. Di Amerika Serikat sebagaimana yang diungkapkan oleh Corporate Crime Reporter pada tanggal 3 Juli 2003 dengan judul, Dirty Money: Corporate Criminal Donations to the two Major Parties. ${ }^{19}$ Dalam laporan itu dikemukakan bahwa partai politik seharusnya tidak menerima uang dari korporasi jahat, ketika skandal WorldCom, ImClone, dan Enron sedang merebak, para politikus dari kedua partai politik (Republik dan Demokrat) di bawah pengawasan yang ketat dari pers agar mengembalikan sumbangan kepada perusahaan-perusahaan penyumbang. Namun, kedua partai besar itu secara rutin menerima jutaan dollar dari korporasi jahat. Selanjutnya, dilaporkan bahwa terdapat lebih dari 31 korporasi jahat menyumbang $\$ 9.3$ juta kepada partai Demokrat dan Republik selama putaran pemilu 2002. Sumbangan yang diterima oleh partai Republik berjumlah $\$ 7.2$ juta (77\%) dan $\$ 2.1$ juta kepada Demokrat (23\%). Lima diantaranya merupakan penyumbang terbesar terhadap kedua partai tersebut adalah: Archer Daniels Midland ( $\$ 1.7$ juta); Pfizer ( $\$ 1.1$ juta); Chevron $(\$ 875,400)$; Northrop Grumman $(\$ 741,250)$; dan American Airlines $(\$ 655,593)$. Untuk Indonesia, misalnya, sumbangan dana kampanye yang beraroma pencucian uang kemungkinan dapat terjadi pada level pemilihan anggota DPR, DPD, DPRD, Pilpres sampai pada Pilkada.

\section{Simpulan}

Dalam struktur kejahatan transnasional yang terorganisasi, money laundering selain sebagai salah satu kejahatan lanjutan, juga merupakan sarana dari berbagai jenis kejahatan yang termasuk dalam organized crime untuk mengaburkan asal-usul perolehan kekayaannya. Misalnya, uang hasil korupsi, diupayakan oleh pelakunya untuk disembunyikan sumber perolehannya. Sarana untuk proses penyembunyian itu, baik melalui bank maupun non bank sebagaimana yang sudah lazim dibicarakan orang selama ini, tapi dalam perkembangannya tidak menutup kemungkinan merambah kepada pembiayaan Pilkada

\footnotetext{
${ }^{19} \mathrm{http}: /$ www.corporatecrimereporter.com/ccrreport.pdf
} 
sebagai start awalnya. Selanjutnya, jika calon kepada daerah yang didukung itu menang, maka pencucian uang dapat dilakukan dalam berbagai proyek.

Mengingat Pilkada secara langsung baru diadakan dalam tahun 2005, namun bukan berarti tertutup kemungkinan bagi aparat penegak hukum untuk menelusuri kemungkinan terjadinya pencucian uang dalam kegiatan Pilkada tersebut. Apabila penelusuran itu berhasil dilakukan, maka ancaman terhadap nilai-nilai demokrasi akan dapat diatasi, sehingga dalam pelaksanaan Pilkada tetap berada dalam bingkai etika dan tidak melanggar hukum, dan masyarakat pun puas karena pimpinannya yang tampil adalah memang sesuai dengan pilihannya.

\section{Daftar Pustaka}

Amrullah, M. Arief, 2003, Money Laundering, Tindak Pidana Pencucian Uang, Malang: Bayumedia Publishing

Ball, Harry V. and Lawrence M. Friedman, 1977, The Use of Criminal Sacntions in the Enforcement of Economic Legislation: A Sociological View, dalam Gilbert Geis and Robert F. Meier, (ED), White-Collar Crime: Offenses in Business, Politics, and the Professions, New York: The Free Press, A Division of Macmillan Publishing Co., Inc.

Balakrishnan, 1973, "Reform of Criminal in India Some Aspects," dalam Resource Material Series No. 6, UNAFEI, Fuchu, Tokyo, Japan, Oktober 1973.

Box, Steven, 1983, Power, Crime, and Mystification, London \& New York: Tavistock Publication.

Kadish, Sanford H., 1977, "Some Observations on the Use of Criminal Sanctions in
Enforcing Economic Regulations," dalam Gilbert Geis and Robert F. Meier, (ED), White-collar Crime: Offenses in Business, Politics, and the Professions, New York: The Free Press, A Division of Macmillan Publishing Co., Inc.

Moens, Gabriel A., 1994, "Bank Confidentiality and Governmental Control of Exchange Operations and of Their Uniawful Effects - Australia", dalam Paolo Bernasconi (ED), "Money Laundering and Banking Secrecy", General Report of XIVth International Congress of Comparative Law, Athens, 1994, London: Kluwer Law International.

Nilsson, Hans G., 1994, Preface, dalam Paolo Bemasconi (ED), "Money Laundering and Banking Secrecy," General Report of XIVth International Congress of Comparative Law, Athens, 1994, London: Kluwer Law Intemational

Reksodiputro, Mardjono, 1994, Sistem Peradilan Pidana Indonesia (Peran Penegak Hukum Melawan Kejahatan), dalam Mardjono Reksodiputro, Hak Asasi Manusia dalam Sistem Peradilan Pidana, Jakarta: Pusat Pelayanan Keadilan dan Pengabdian Hukum, Lembaga Kriminologi, Universitas Indonesia ,1997, Kemajuan Pembangunan Ekonomi dan Kejahatan, Jakarta: Pusat Pelayanan Keadilan dan Pengabdian Hukum, Lembaga Kriminologi, Universitas Indonesia ,1997, Bunga Rampai Permasalahan dalam Sistem Peradilan Pidana, Jakarta: Pusat Pelayanan Keadilan dan Pengabdian Hukum ( $d / h$ Lembaga Kriminologi) Universitas Indonesia 
,2000, "Kejahatan Terorganisasi dan Kejahatan oleh Organisasi (Suatu Tinjauan dari Segi Kriminologi," Jurnal Polisi Indonesia, Tahun 2, April 2000 September 2000, Jakarta: Program Pascasarjana Kajian IImu Kepolisian Universitas Indonesia bekerjasama dengan Yayasan Obor Indonesia.

Commission on Crime Prevention and Criminal Justice, Strengthening Existing International Cooperation in
Crime Prevention and Criminal Justice, Including Technical Cooperation in Developing Countries, with Special Emphasis on Combating Organized Crime, First session, Vienna, 21-30 April 1992.

World Ministerial Conference on Organizied Transnational Crime, "Problem and Dangers Posed by Organized Transnational Crime in the Various Regions of the World," Naples, 21-23 November 1994. 